\title{
LEARNING FOREIGN LANGUAGES THROUGH BLENDED LEARNING
}

\author{
Basori \\ English Department, Faculty of Humanities, Bina Nusantara University \\ basori@binus.edu
}

\begin{abstract}
Blended learning is gaining popularity as an effective method to deliver courses. Foreign language instruction is adopting opportunities to apply blended learning. This paper looks at the essence of blended learning and foreign language instruction by defining those two terms. The literature has clearly unveiled the principles of each learning method that constitutes foreign language delivered via blended learning. It leads to major elements that need to be considered when designing blended foreign language instruction. Sufficient input, adequate interaction, plenty of feedback, and meaningful tasks are major components of building blended foreign language courses. Some recent studies have successfully implemented those principles in designing blended learning foreign language instruction; however, the studies also disclose some challenges.
\end{abstract}

Keywords: blended learning, foreign language learning, foreign language instructions

\begin{abstract}
ABSTRAK
Blended learning semakin populer sebagai metode yang efektif dalam kegiatan pengajaran. Metode ini juga diterapkan dalam pengajaran bahasa asing. Artikel ini membahas esensi blended learning dan pengajaran bahasa asing dengan mendefinisikan kedua istilah tersebut. Telah banyak studi literatur yang membahas dan mendiskusikan tentang prinsip-prinsip metode pembelajaran bahasa asing yang disampaikan melalui blended learning. Ini mengarah pada elemen-elemen inti yang perlu dipertimbangkan dalam merancang pengajaran bahasa asing yang disampaikan melalui blended learning. Input yang cukup, interaksi yang memadai, adanya umpan balik yang memadai, dan tugas yang bermakna adalah komponen-komponen utama yang perlu diperhatikan dalam pengajaran bahasa asing yang menerapkan blended learning. Beberapa studi terbaru telah berhasil menerapkan prinsip-prinsip tersebut dalam merancang pembelajaran bahasa asing yang menerapkan blended learning. Di sisi yang lain, artikel ini juga memaparkan beberapa tantangan pengajaran bahasa asing yang menerapkan metode blended learning.
\end{abstract}

Kata kunci: blended learning, pembelajaran bahasa asing, pengajaran bahasa asing 


\section{INTRODUCTION}

When learners study a language, they try to master language skills; listening, speaking, reading, and writing, culture, and language components such as vocabulary and grammar. All of those components support one another such that the inability to master one of them will lead learners to be unable to communicate the language properly. Therefore, there should be a way to accommodate the needs that students have when learning a language.

In order to learn a foreign language, the learners need a lot of exposure to the target language. They need to have interaction with native speakers, preferably representing the target country (Blake, 2009). In other words, engaging in natural interaction is preferable. Learners often have to study abroad for total language immersion since it is believed to be effective in acquiring the target language (Davidson, 2010; Llanes \& Muñoz, 2013; Shively, 2013). However, to visit the target language country, the learners need to allocate significant amounts of money and it has to be done at a particular time, which provides little flexibility.

With the development of technology and learning management systems such as Moodle and Blackboard, many courses, including foreign language courses, are possible to be offered via blended learning. Blended learning can accommodate two-way communication such as interactivity and collaboration, which are essential parts of foreign language learning. Not only that, the learners will have more opportunities to learn outside the class (Eryilmaz, 2015). They will have access to abundant learning materials which are authentic and contain more knowledge of the target culture of the language. The presence of online media will also allow them to find native friends that they can communicate with in a target language which supports social interaction after the classroom meeting (Eriyilmaz, 2015). In other words, blended learning has shown advantages in language learning.

Looking at this possibility, this paper review will discuss the use of blended learning in foreign language learning, which is then broken down into several subtopics. In order to get a clear idea of the topic, the first focus will present the definition of blended learning and the nature of foreign language instruction. Then, the paper will discuss why blended learning is used as a way to learn foreign languages in connection with the nature of foreign language instruction, especially the effectiveness of two-way communication. Then, the second subtopic will include some principles that need to be considered in designing learning foreign language through blended learning. The paragraphs will discuss characteristics of effective designing for learning a foreign language through blended learning. The third topic will cover the practice of learning a foreign language through blended learning. It will present the successful implementation of foreign language learning presented via blended learning education as well as some challenges of blended learning. Although there have been many success stories, the paper will present possible challenges of learning a foreign language via blended learning.

\section{METHOD}

This paper aims to present the opportunities of using blended learning in foreign language instructions. In order to discuss and present the issues, 
this paper employs literature review papers (LRPs). The principle data of the paper are taken from journal articles, academic books, and other academic resources upon the topic (MonganRallis, 2018). Further, this paper covers only specific theme in the area on blended learning in foreign language instruction. It is one of the alternative types of LRs in which not "all main literature" are reviewed (Wee \& Banister, 2016:283).

The collection of printed and online peer review articles, and other relevant resources are gathered from online database and library archive. The words used when searching articles in online database are blended learning, foreign language learning, and foreign language instructions. In addition, since blended learning and instructions are fast evolving, the articles used as resources in this paper are those which are published in the year of 2000 above. This decision is taken so that the paper presented are still up to date and relevant. Furthermore, the writer doesn't not limit the categories of countries where studies are conducted. The purpose is to get wider insight of the past research upon the use of blended learning in foreign language learning.

\section{DEFINITION OF BLENDED LEARNING AND THE NATURE OF FOREIGN LANGUAGE INSTRUCTION}

Shrum and Glisan (2010) define the term of blended courses interchangeably with hybrid courses. In line with that definition, Yuping, Xibin, and Juan (2015:380) state that the term is also known as "mixed mode learning" or "technology-mediated/enhanced learning". Graham (2006) and Krasnova and Sidorenko (2013) and Shrum and Glisan (2010) have the same notion that blended learning is a type of learning that combines the computer as a media of instruction and face-to-face instruction. It integrates the attribution of both synchronous and asynchronous learning (Yoon \& Lee, 2010:180).

Nielson, Gonzalez-Lloret, and Pinckney (2009) present the efficiency of a hybrid course. They believe that the efficiency happens when concepts are presented during in-person meetings, which are then followed by application and reinforcement outside the class or conversely. The face-to-face class (synchronous) present learners with the same benefit as in bricks and mortar classroom since they can engage in a discussion that occurs at the actual time of learning; asynchronous meetings give learners more of chances to study and review their learning (Alexander, Lynch, Rabinovich, \& Knutel, 2014). These two types of meetings provide an ideal environment for learners to work together in which they actively build their knowledge (Yoon \& Lee, 2010). In addition, based on the primary purpose of blending, Graham (2006) defines three categories of blended learning systems, and those are 1) blending that provides different modality in order to give more for flexibility and the same learning experience, 2) blending that allows additional materials without changing the pedagogy, and 3) transforming blend in which pedagogical changes can occur such as from teacher-centered to studentcentered instruction. Therefore, blended learning combines the positive sides of those two instructional methods (Bonk \& Graham, 2012) when they are implemented properly (White, 2006).

The aforesaid descriptions are in line with the goal of learning a foreign language, which is facilitating learners to be able to communicate effectively. In order to communicate effectively, the 
input that the learners received should be actively negotiated (Shrum \& Glisan, 2010). The input should be widely varied (Nielson, Gonzalez-Lloret, \& Pinckney, 2009) and learners need to comprehend information that they are accessing (Isiguel, 2014). Furthermore, in order to facilitate language acquisition, Shrum and Glisan (2010) state that foreign language instructions have to provide an environment that supports self-expression, allows a twoway flow of information, gives chances for learners to communicate among their peers in the target language, and provides meaningful activities and work. The environment should make learners use the target language and foster communication and interaction either with their friends or with native speakers (Nielson, Gonzalez-Lloret, \& Pinckney, 2009). Those elements will facilitate learners to produce an output that can be seen when learners produce the target language they are learning. However, both sufficient input and more opportunities to communicate are not enough since learners also need feedback, which facilitates correction and revision (Doughty \& Long, 2003; Nielson, Gonzalez-Lloret, \& Pinckney, 2009). Given these advantages, blended learning has been adopted in teaching and learning foreign language.

\section{PRINCIPLES OF DESIGINING FOREIGN LANGUAGE INSTRUCTION IN BLENDED LEARNING}

Blended learning comprises face-to-face teaching techniques and online interactive collaboration with the use of technology. Even though this type of learning consists of two types of instruction, both of them are mixed into a system that corresponds to each other and constructs one environment (Krasnova \& Sidorenko, 2013). The environment of blended foreign language instruction should meet students' needs in order to master a target language. Input, interaction/output, feedback, and focus on task need to be considered in creating an effective foreign language program such as a blended system (Krasnova \& Sidorenko, 2013). The input that learners need must be optimally comprehensible, interesting, a bit beyond their current competence, not grammatically sequenced and given in an environment that does not press the learners (Krashen, 1982). The input must be meaningful and contextual to support language acquisition (Shrum \& Glisan, 1994) and blended learning emphasizes the use of computer-based technology integration (Graham, 2006). It is the job of the instructors to provide such environments. Besides providing authentic discourse so that the input is comprehensible, Nielson, GonzalezLloret, and Pinckney (2009) say that instructors should allow exploration of supplemental input, create assignments that promote engaging activities and allow learners to exercise their listening skills and support constructive learning.

The second major principal in blended foreign language instruction is the presence of interaction. Since blended learning takes the advantages of face-to-face and online instruction, it can present two types of interactions, both human and non-human interaction (Archila, 2014). The non-human interaction, which is translated as computer-mediated communication, includes students' interaction with tools, environments, and contents (Archila, 2014). Therefore, the foreign language blended instruction should present these types of interactions and give assignments that challenge learners to communicate, either spoken or written using target languages and interact 
preferably with more fluent speakers of the target language that can be geared toward meaningful activities and maximize learning (Nielson, GonzalezLloret, \& Pinckney, 2009). The interaction can build a sense of community that allows learners to work collaboratively (Banados, 2006). Since technologies are addressed and used, the interactions allow students to communicate asynchronously using blogs or record their voice, which brings many advantages for shy and reserved students in bricks and mortar type of classroom (Nielson, Gonzalez-Lloret, \& Pinckney, 2009). To sum up, the interaction in blended learning does not merely help learners to master the language, but it helps build students' competence, especially their confidence.

Feedback becomes the third important principle besides input and output/interaction in designing foreign language instruction in blended learning. Blended instruction gives more ways of providing feedback that does not only rely on paper and pencil but also make use of computer-mediated tools, which provide greater opportunities not only in terms of language form and content, but also in the form of communication (Tolosa, Ordonez, \& Alfonso, 2015). With that said, the instructors should provide appropriate feedback on learners' performances so that learners will gain competence. Feedback is central for learning and improving performance (Gyamfi \& Gyaase, 2015). Nielson, Gonzalez-Lloret, and Pinckney (2009) also state that instructors should provide feedback frequently, promote peerfeedback, facilitate interactive feedback, and give feedback during the learning process and after learners have produced their output. Further they say, giving feedback after reviewing learners' learning output allows teachers to know the learners' learning progress. Feedback leads to deeper comprehension of learners' learning since it helps learners find any inadequate performance and it involves iterative information gathering from others (Hwang \& Arbaught, 2009). In conclusion, leaving out feedback is a drawback to learning a foreign language.

The last major principle of designing effective blended foreign language programs is task focus. Although abundant access to language inputs are provided by the multimodality of the Internet, the blended foreign language instruction should also incorporate meaningful activities that relate to students' needs and also take into account design tasks that increase the level of complexity (Nielson, Gonzalez-Lloret, \& Pinckney, 2009). The multimodality of the Internet can be in the form of using online virtual worlds such as Second Life, which offers not only fun learning and engaged learning that can boost students' motivation, this 3D learning environment also enhances collaboration, autonomous learning, and adds cultural literacy about the target language (Aydin, 2013). Learners can also study from audiovisual media. Video is one of the audiovisual media that learners get benefits from by analyzing language features such as grammar, phrases, and/or slang features (Molchanova, 2014). Furthermore, through meaningful tasks authentic language learning activities can utilize wide ranges of language input through audiovisual mass media technologies (Bahrani and Sim, 2012). Blended learning allows foreign language learners to explore input, do collaborative work, and communicate with the native speakers of the target language, which can create meaningful 
learning (Nielson, Gonzalez-Lloret, \& Pinckney, 2009). In other words, careful design of tasks determines the level of the meaningfulness of the learning.

\section{BLENDED LANGUAGE LEARNING IN PRACTICE AND CHALLENGES FACED}

Blended learning has been applied in teaching foreign languages since it brings advantages to foreign language learners. The study conducted by Banditvilai (2016) shows significant benefits of blended learning in language education. The study reveals that students' language skills are improved through blended learning as well as their motivation. When students' motivation is high, their sense of independence in learning is also high (Banditvilai, 2016).

In teaching L2 writing, Yoon and Lee (2010) have revealed that blended learning is effective in facilitating the four components of L2 writing, namely mechanics, content, organization, and structure. So and Lee (2013) who investigated students' perspectives and effectiveness of blended learning in L2 writing also found the same benefits of blended learning, especially in promoting adequate feedback and giving learners more time to do drafting as well as revision. In other words, compared to synchronous meetings the types of discussion that can occur without having face-to-face meetings give learners sufficient time to pay attention to stylistic form, which covers planning, checking spelling, grammar, and punctuation (Moradi \& Karimpour, 2012).

Besides the above advantages, $\mathrm{Hu}$ (2012), who reviews Chinese language courses, concludes that blended learning enables learners to achieve a satisfactory result in knowledge of vocabulary and Chinese characters, grammar, and enhances their reading skills as well. In addition to developing language competencies, the course opened more chances for learners' career development since the course involved many project opportunities and professional contacts (Hu, 2012). Molchanova (2014) identified that blended learning also has a positive impact in increasing students' motivation and independence in learning.

In addition to the above benefits, Kim (2015) has found out that blended learning is also effective in learning cultural aspects and facilitating learners in exercising their oral production skills, since this type of instruction fosters engagement with native speakers and promotes learners' empowerment. Although the research conducted by Bissoonauth-Bedford and Stace (2012) focused on embedding peer learning in an online discussion, they also found that combining both online discussion and face-to-face learning is advantageous for improving learners' cultural perspectives of the target language in addition to linguistic mastery. Further they note, the mix of two learning methods promotes learners' interaction, boosts knowledge, and develops their grammar acquisition outside of synchronous meetings (Bissoonauth-Bedford \& Stace, 2012). Although it seems that learners are exposed to various language inputs, the learners have time to relax with the language (Gleason, 2013). Furthermore, Gleason (2013) in a study of a blended Spanish course also adds that this type of class triggers the more reserved students to increase their contributions to online class discussions.

Due to the fact that there are many advantages of foreign language being delivered via blended learning 
instruction, some challenges lie ahead. The instructors who teach foreign language via blended learning should accommodate students' needs, provide more assistance when they find difficulties to promote deeper learning (Bissoonauth-Bedford \& Stace, 2012) and should also have enough training and resources in order to successfully teach the class (So \& Lee, 2013; Yoon $\&$ Lee, 2010). The training should also include additional blended learning in terms of e-learning resources and technology (Hu, 2012). Besides, the institution also needs to provide technical infrastructure involving both human and non-human resources, and select course designers that can address technology in the learning outcome as well as develop e-learning materials (Nielson, Gonzalez-Lloret, \& Pinckney, 2009). Continuous assessment and evaluation of blended learning application should be one of the routine agenda that the educational institution has (Lalima \& Dangwal, 2017). The purpose is to monitor the progress of blended learning implementation.

Students of blended language learning also need to have a high time commitment since the classes are delivered in two formats (Gleason, 2013). Besides that, many students still lack interaction among their peers not because they do not want to, but because they lack adequate knowledge of the technology tools used in learning (Archila, 2014). It implies that learners also need to have training or preparation before joining any blended language learning or at least be provided with plenty of resources to learn the technology. Yuping, Xibin, and Juan (2015) offer complex adaptive system frameworks of blended learning as the solution for bridging gaps that exist in blended learning. It indicates that the systems of blended learning have not yet been seen as an integrated whole.

In addition to the above, if blended learning is applied in $\mathrm{K}-12$, learners' parents should also take this into account. Lalima and Dangwal (2017) note that parents should be informed regarding the blended learning approach as their children will study using this approach. They should be fully aware that this approach is different from the traditional classroom teaching yet the benefits are more than the bricks and mortar classroom approach. The information given to the parent is crucial so that the children have full support from their parents (Lalima \& Dangwal, 2017).

All those issues have added more challenges that have to be solved for the future of blended learning, especially when dealing with foreign language learning.

\section{CONCLUSION}

Blended learning has integrated the benefits of face-to-face and online instruction, and each type of learning complements the other's deficiency to build an ideal learning environment that can support foreign language learning. It is not a simple task to do since designing and adopting blended language courses consumes more time and involves many entities such as the institution, course designers, and the instructors (Nielson, Gonzalez-Lloret, \& Pinckney, 2009). They work as one system and should not be separated (Yuping, Xibin \& Juan, 2015).

A good quality of foreign language delivered via blended learning should bring students maximum advantages. By giving more opportunities to have interaction with the more advanced target language speakers or possibly with native speakers, having more than sufficient 
language input, receiving enough feedback, and accessing meaningful resources and activities, learners will face fewer difficulties learning the language. To a greater extent, learners can also develop their non-academic sense, such as that of autonomy (Yoon $\&$ Lee, 2010) and motivation (Aydin, 2013) that actually correlate to their success of learning.

The writer believes that the aforementioned aspects of designing blended learning should become pivotal points that are taken into account in designing blended learning for foreign language teaching. A balanced proportion of each aspect should always be maintained to keep students always engaged with the class. It is crucial to avoid students' attrition which becomes one of the fears of blended learning.

Many studies have been conducted and successfully implemented regarding blended learning to teach foreign languages. However, this situation will not stop any further studies to uncover the other hidden potential and solve any crucial issues. Part of it is because blended learning employs computer-mediated technologies (Krasnova \& Sidorenko, 2013) and the internet (Molchanova, 2014) that continue to develop. All of those activities are aimed at providing convenient foreign language instruction that meets the needs of learners.

Therefore, future studies should take into account all the principles addressed; the input, presence of interaction, adequate feedback, and sufficient task focus in designing blended learning of foreign language instruction. By incorporating those aspects, all the challenges that are currently faced can be diminished.

\section{REFERENCES}

Alexander, M. M., Lynch, J. E., Rabinovich, T., \& Knutel, P. G. (2014). Snapshot of a hybrid learning environment. Quarterly Review of Distance Education, 15(1), 9.

Archila, Y. M. R. (2014). Interaction in blended environment for English language learning. Gist Education and Learning Research Journal, 9, $142-156$

Aydin, S. (2013). Second Life as a foreign language learning environment: A review of research. Turkish Online Journal of Distance Education, 14(1), 5363.

Bahrani, T., \& Sim, T. S. (2012). Informal language learning setting: Technology or social interaction? Turkish Online Journal of Educational Technology, 11(2), 142-149.

Banados, E. (2006). A blended-learning pedagogic model for teaching and learning EFL successfully through an online interactive multimedia environment. CALICO Journal, 23(3), 533-550.

Banditvilai, C. (2016). Enhancing students' language skills through blended learning. The Electronic Journal of e-Learning 14(3), 220229.

Bissoonauth-Bedford, A., \& Stace, R. (2012). Grappling with grammar on a virtual learning platform: The case of first year French Students at the University of Wollongong. Journal of University Teaching and Learning Practice, 9(1), 2.

Blake, R. (2009). From web pages to distance learning: Technology in the foreign language curriculum. In Lancashire, I (Ed.), Teaching Literature and Language Online. 23-37. 
Bonk, C. J., \& Graham, C. R. (2012). The handbook of blended learning: Global perspectives, local designs. John Wiley \& Sons.

Davidson, D. E. (2010). Study abroad: When, how long, and with what results? New data from the Russian front. Foreign Language Annals, 43(1), 6-26.

Doughty, C. J., \& Long, M. H. (2003). Optimal psycholinguistic environments for distance foreign language learning. Language Learning \& Technology, 7 (3), 5080.

Eryilmaz, M. (2015). The effectiveness of blended learning environments. Contemporary Issues in Education Research 8(4), 251-256

Gleason, J. (2013). Dilemmas of blended language learning: Learner and teacher experiences. CALICO Journal, 30(3), 323-341.

Graham, C. R. (2006). Blended learning systems: Definition, current trends, and future directions. In C. J. Bonk \& C. R. Grahams (Eds), Handbook of blended learning: Global perspective, local designs (pp.3-21). San Francisco: Pfeiffer.

Gyamfi, S. A. \& Gyaase, P. O. (2015). Students' perception of blended learning environment: A case study of the University of Education, Winneba, Kumasicampus, Ghana. International Journal of Education and Development using Information and Communication Technology (IJEDICT), 11 (1), 80-100.

$\mathrm{Hu}$, B. (2012). The challenges of blended learning: Critically evaluating the Chinese language case. European Association for Computer Assisted Language Learning, 80.

Hwang, A., \& Arbaugh, J. B. (2009). Seeking feedback in blended learning: Competitive versus cooperative student attitudes and their links to learning outcome. Journal of Computer Assisted Learning, 25(3), 280-293.

Isiguel, B. (2014). The blended learning environment on the foreign language learning process: A balance for motivation and achievement. Turkish Online Journal of Distance Education, 15(3).

Kim, M. (2015). Korean EFL students' interactional challenges and ways to overcome them in blended learning. Multimedia-Assisted Language Learning, 18(2), 59-87.

Krashen, S. D. (1982). Child-Adult Differences in Second Language Acquisition: Series on Issues In Second Language Research. Rowley, MA: Newbury House Publishers, Inc.

Krasnova, T., \& Sidorenko, T. (2013). Blended learning in teaching foreign languages. In Conference proceedings. ICT for language learning (p. 45). Retrieved from http://portal.tpu.ru:7777/SHARE

D/k/KRASNOVA/science/Tab1/1 13-ELE08-FP-SidorenkoICT2013_0.pdf.

Lalima \& Dangwal, K. L. (2017). Blended learning: an innovative approach. Universal Journal of Education Research 5(1), 129-136

Llanes, À., \& Muñoz, C. (2013). Age effects in a study abroad context: Children and adults studying abroad and at home. Language Learning, 63(1), 63-90. doi:10.1111/j.14679922.2012.00731.x

Molchanova, I. I. (2014). Influence of the Internet on Studying English. International Education Studies, 8(1), 133. 
Mongan-Rallis, H. (2018, April 19). Guidelines for writing a literature review. Retrieved from http://www.duluth.umn.edu/ hrall is/guides/researching/litreview.ht $\mathrm{ml}$

Moradi, M. R., \& Karimpour, Z. (2012). The effect of online peer feedback on the academic writing ability of Iranian EFL learners. International Education Studies, 5(2), 113.

Nielson, K., Gonzalez-Lloret, M., \& Pinckney, K. (2009). Learning foreign languages at a distance. Retrieved from http://www.casl.umd.edu/sites/def ault/files/Nielson09_LearningFore ignLang_0.pdf.

Shively, R. L. (2013). Out-of-class interaction during study abroad service encounters in Spain. Spanish in Context, 10(1), 53-91. doi:10.1075/sic.10. 1.03shi

Shrum, J. L. \& Glisan, E. W. (2010) Teacher's handbook:

Contextualized Language Instruction. Boston, MA: Heinle Cengage.

Shrum, J. L. \& Glisan, E. W. (1994) Teacher's handbook: Contextualized language Instruction. Boston, MA: Heinle \& Heinle.

So, L., \& Lee, C. H. (2013). A case study on the effects of an L2 writing instructional model for blended learning in higher education. Turkish Online Journal of Educational TechnologyTOJET, 12(4), 1-10.

Tolosa, C., Ordóñez, C. L., \& Alfonso, T. (2015). Online peer feedback between Colombian and New Zealand FL beginners: A comparison and lessons learned. Profile Issues in Teachers
Professional Development, 17(1), 73-86.

Wee, B. V., \& Banister, D. (2016). How to write a literature review paper?, Transport Reviews, 36(2), 278288.

White, C. (2006). State of the art review article: The distance learning of foreign languages. Language Teaching, 39(4), 247-264.

Yoon, S. Y., \& Lee, C. H. (2010). The perspectives and effectiveness of blended learning in L2 writing of Korean university students. Multimedia Assisted Language Learning, 13(2), 177-204.

Yuping, W., Xibin, H., \& Juan, Y. (2015). Revisiting the blended learning literature: Using a Complex Adaptive Systems Framework. Journal of Educational Technology \& Society, 18(2), 380-393. 